\title{
Doing Business Research and Teaching Methodology for Undergraduate, Postgraduate and Doctoral Students - Case in Various Markets Including Vietnam
}

\author{
*Duong Thi Tinh, Thai Nguyen University of Economics and Business Administration (TUEBA), Thai \\ nguyen, Vietnam. \\ Nguyen Thu Thuy, Thai Nguyen University of Economics and Business Administration (TUEBA), Thai \\ nguyen, Vietnam. \\ *Dinh Tran Ngoc Huy, Banking University HCMC, Ho Chi Minh city Vietnam - International University of \\ Japan, Japan. \\ *corresponding Author
}

\begin{abstract}
This paper use qualitative analysis with statistics to propose recommendations for teaching methodology to students at all levels from undergraduate schools to doctoral and even associate professors. For undergraduate students, we need to equip students with foundation knowledge to enter business work and work environment, knowledge including politics, economic or technology, language (English, Chinese, Japanese, etc.) and sports. For post graduate level, we need to train students both English and computer skills to produce qualified reports for management and write economic, marketing and management reports. For doctoral level, we need to train the how to use English to communicate, write and produce very good articles to publish in famous journals such as ISI, Scopus, ABDC high rank, etc. For all three levels (undergraduate, postgraduate, doctoral) students need to be trained and equipped with foreign language, esp. English using skill in job, business and scientific research and life. The limitation of this study is that it needs to collect data and then expand for other emerging markets as well.
\end{abstract}

Keywords: teaching method, Vietnam, doctoral, postgraduate, undergraduate level, language skill, scientific research.

Received: 10.11.2020 $\quad$ Accepted: $16.12 .2020 \quad$ Published: 19.01 .2021

\section{INTRODUCTION}

There are 2 research questions in this study:

Question 1: What students need fro all levels from undergraduate, postgraduate to doctoral and associate professors?

Question 2: What are recommendations for teaching methodology to develop students skills?

\section{LITERATURE REVIEW}

In a world with ever increasing international competitive pressures, English abilities are proposed to be an important component of participating in the global economy (Wedell 2008, and Warschauer 2000.) The benefits of learning English to an individual are readily identified- higher paying employment- the costs may prove to be too high as one is forced to choose between language skills and other forms of human capital (Wedell 2008.)

Nickels (2000) presented a strategy for the teaching digital electronics to undergraduates with the use of computer-aided design (CAD) tools and hardware description languages. A hierarchical strategy was utilized, and this involved having students beginning with the study of simple digital electronic circuits after which they progressed to problems involving more complex digital electronic. Nickels (2000), however, did not conclude whether the methodology implored led to any benefit in the area of student learning or performance.

Hejazi and Ma (2011)finds that two countries that both speak English have more bilateral trade than two countries who have a similar shared language that is not English. Next, Omar (2016) recommended to abolish the classical literary components of the language programs currently prevailing to be replaced with market place language skills, such as ESP ones, which focus on workplace related skills such as proposal writing, letter writing, emailing, research writing, negotiation skills, public relations language skills and oral communication skills. Shrestha et al. (2018) sheds light on the facts that the English language proficiency is extremely important for the global engineers today. It reveals that the 
ability to communicate in English efficiently in their workplace is of paramount importance for engineers not only in Nepal but also in the other countries.

Besides, Mishra et al (2020) seeks to address the required essentialities of online teachinglearning in education amid the COVID-19 pandemic and how can existing resources of educational institutions effectively transform formal education into online education with the help of virtual classes and other pivotal online tools in this continually shifting educational landscape. The paper employs both quantitative and qualitative approach to study the perceptions of teachers and students on online teaching-learning modes and also highlighted the implementation process of online teaching-learning modes. The value of this paper is to draw a holistic picture of ongoing online teaching-learning activities during the lockdown period including establishing the linkage between change management process and online teaching-learning process in education system amid the COVID-19 outbreak so as to overcome the persisting academic disturbance and consequently ensure the resumption of educational activities and discourses as a normal course of procedure in the education system.

George (2020) presented effective teaching and examination strategies that can be utilized for undergraduate learning of courses during COVID-19 school restrictions. To demonstrate the use of these strategies the teaching and examination of the introductory digital electronics course of the Department of Electrical and Computer Engineering, UWI, St. Augustine campus was utilized. The article also served to demonstrate that the application of such teaching methodologies to the introductory digital electronics course avoided the student performance from degrading below what has been experienced in the past five academic years, despite the presence of COVID-19 school restrictions.

Then, Saeed and Qunayeer (2020) revealed three types of challenges: student-oriented challenges, subject-matter-related challenges and instructor-oriented challenges. Three main pedagogical strategies: instructional scaffolding, peer scaffolding and engaging the postgraduates in drafting their tasks were employed as a response to these challenges. Although the active teaching and learning practices resulted into students' enhancement of the assigned research methodology tasks and positive research learning experience, such practices were time and effort-consuming. Therefore, future research will need to examine the applicability of our active teaching and learning approach to research methodology courses in different contexts.

Last but not least, Patricia et al (2020) said that It is clear that a range of theories and teaching methods are used in postgraduate health science education, with educators feeling the need to explore more innovative methods.

And Rapanta et al (2020) point at the design of learning activities with certain characteristics, the combination of three types of presence (social, cognitive and facilitatory) and the need for adapting assessment to the new learning requirements. We end with a reflection on how responding to a crisis (as best we can) may precipitate enhanced teaching and learning practices in the postdigital era.

\section{METHOD AND DATA}

This study mainly use qualitative analysis, combined with experience teaching, expertise discussion, dialectical materialism methods and with statistical data in order to analyze, synthesis and generate recommendations to develop teaching methodology for improving students computer and language skills.

\section{MAIN RESULTS}

\section{Findings on teaching method to enhance student's computer skills}

At undergraduate level: Students get familiar with using computer software to finish homeworks, exercises, thesis, reports, etc.

At post graduate level: Students use computers to produce economic and management in work environment fluently.

At doctoral level: Students get familiar with using computers for publishing articles in local and well known international journals.

At Associate professor level: learners need to use advanced computer skills in doing research and publish articles and books in well know publishers (ISI, WoS, Scopus, etc.)

\section{Findings on teaching method to enhance student's language skills}

In the era of 4.0 technology revolution, our Vietnamese students also need to keep pace with both technology and esp., language practices, esp. in the context that Vietnam in high rank in attracting foreign investment capital (Binh Duong, HCMC and Ha Noi) and there are thousands of ( about 3000 - 5000) new businesses established in every year recently.. Certainly there are many vital skills which our students 
have to obtain in their student life and work or in future life; however, within the scope of this writing, we will mention on the role of language only.

Language practices include several main kinds such as: verbal language and non- verbal language (body language such as gestures, hands, arms, eye contact and face...).

Verbal language include: social communication, fundamental business communication (telephone, email...) and advanced business communication (including meeting, presentation, negotiation, call conference, video conference...), as well as language in technology fields (manufacturing, industrial, computer, technology information).

Social communication skill is very necessary for students to increase communication with friends, co-workers, boss, clients in most of industries, esp. sale and service industries such as banking, insurance, stock...

Fundamental business communication will help students to overcome obstacles during the $1^{\text {st }}$ three years of working, due to lack of practical experience. Knowing how to talk with and listen to customers and colleagues are basic for us during this stage. Sometimes you need to talk and write briefly but in specific. Nowadays writing informal and formal email, adding email signature and structuring your email, have been becoming a usual activity in daily business life and it will help our students to introduce themselves, make impact and achieve task goals.

Next, advanced business communication skill will appear as young officers and workers climb to higher levels of career, such as deputy, team leader or manager and even directors, as well as CEO in business. This requires much more efforts from our students and they will practice in a long term plan to achieve it. Meeting, presentation and negotiation skills are among key activities of business life.

Public speaking is necessary for both political, social and business or education environment where our students learn how to deliver messages and communicate effectively with lots of audience. It is also one of keys for future success.

The role of using English and other foreign languages such as Korean, Japanese, Chinese... in job and life has been becoming more necessary as it is the key helps you to open the world. English skill cannot be obtained within a short time, so you need to have a preparation plan from present till future. IELTS, TOEIC, TOEFL....and many other courses are good for your choice and there are various ways to learn it.

Additionally, language skill involves the meanings of writing. Pay attention to your writing in classes now and write different reports and theses, in your future job, you have to know how to write business reports to bosses, existing and potential clients, banks, funds... or governmental bodies. Knowing your audience and tailoring your messages to them effectively are not so easy. Take a note on your key points during your speech, presentation or writing is also good while keeping positive attitude and smile.

Besides, Faculties might have a plan on organizing an Economic - Start up - M\&A and English club to help our students enhance their language practices and communication skill, with finance knowledge. Lecturers of the faculty will guide students with their experience, but vice versa, BDU students also need to put lots of efforts to achieve their long term goals in life and work. Together with this scientific club activity, our courses at faculty also pay attention to this language matter during our study period. Keep in mind our learning spirit "learn - ask - understand - practice".

Why we not prepare for our future job from this time? Going from basic to skill, from social to professional is what we need in this technology era.

\section{Findings on teaching method to enhance students scientific research skills}

Table 1: Thai Nguyen University (TUEBA) Vietnam - Number of scientific research topics offaculty students in the period 2004 - 2014

\begin{tabular}{|l|l|l|l|l|l|l|}
\hline Year & Total & Economics & Accounting & Management & Banking-Finance & $\begin{array}{l}\text { Law- } \\
\text { Management }\end{array}$ \\
\hline $\mathbf{2 0 0 4}$ & 2 & 2 & 0 & 0 & & \\
\hline $\mathbf{2 0 0 5}$ & 8 & 4 & 3 & 1 & & \\
\hline $\mathbf{2 0 0 6}$ & 13 & 5 & 5 & 3 & & \\
\hline $\mathbf{2 0 0 7}$ & 14 & 4 & 7 & 2 & & \\
\hline $\mathbf{2 0 0 8}$ & 6 & 1 & 2 & 3 & & \\
\hline $\mathbf{2 0 0 9}$ & 15 & 6 & 6 & 3 & & \\
\hline $\mathbf{2 0 1 0}$ & 12 & 3 & 7 & 2 & & \\
\hline $\mathbf{2 0 1 1}$ & 8 & 3 & 0 & 5 & & \\
\hline
\end{tabular}




\begin{tabular}{|l|l|l|l|l|l|l|}
\hline $\mathbf{2 0 1 2}$ & 19 & 12 & 4 & 3 & & \\
\hline $\mathbf{2 0 1 3}$ & 21 & 6 & 6 & 9 & & \\
\hline $\mathbf{2 0 1 4}$ & 28 & 10 & 4 & 4 & 1 & 10 \\
\hline
\end{tabular}

(Source: Scientific Management Department 2014)

Through table 1 we see, in general, the number of scientific research topics of the whole school has increased over the years. Although there are uneven fluctuations between years, the proportion of science students in the Faculty of Economics and Faculty of Accounting always accounts for about 50 $70 \%$ of the number of topics of the whole school. It is worth noting that in the academic year $2013-2014$, due to the division and establishment of a number of new Faculties. The result is thanks to the efforts of both teachers and students in the Faculties, especially many teachers who are enthusiastic and dedicated to helping science students, so the quantity and quality of works also increase.

Table 2: Thai Nguyen University Vietnam - Quality of scientific research topic of students in period $2006-2013$

\begin{tabular}{|l|l|l|l|l|l|l|}
\hline \multirow{2}{*}{$\begin{array}{l}\text { Faculty/ } \\
\text { Year }\end{array}$} & \multicolumn{2}{|l|}{ Fairly Good Rank } & \multicolumn{2}{l|}{ Pass Rank } \\
\cline { 2 - 7 } & Economics & Accounting & Management & Economics & Accounting & Management \\
\hline 2006 & 4 & 3 & 1 & 0 & 2 & 2 \\
\hline 2007 & 3 & 6 & 2 & 1 & 0 & 1 \\
\hline 2008 & 1 & 1 & 2 & 0 & 1 & 1 \\
\hline 2009 & 6 & 4 & 2 & 0 & 2 & 0 \\
\hline 2010 & 3 & 3 & 2 & 0 & 4 & 0 \\
\hline 2011 & 2 & 0 & 5 & 1 & 0 & 0 \\
\hline 2012 & 8 & 3 & 2 & 4 & 1 & 1 \\
\hline 2013 & 4 & 5 & 7 & & 1 & 1 \\
\hline
\end{tabular}

(Source: Scientific Management Department 2014)

This is the result reflecting the quality of scientific research works of students over the past time. In fact, scientific research among students is being viewed as a movement activity. Not many students are really passionate about the scientific research activities - which is considered one of the key activities of university training.

\section{Findings on teaching method to enhance students self-learning skills:}

Group-work or teamwork will motivate learning spirit of students and individual assignments with tutor support is important for developing students self learning skills.

At postgraduate level, giving reading task for students (book reading) can be a good way to develop their self learning skill.

At doctoral level, assigning individual papers and articles will help to increase students self learning skills.

\section{DISCUSSION}

At undergraduate level: Students get familiar with using English in their specialised industries: banking, technology, manufacturing, medicine, tourism, etc.

At post graduate level: Students use English in communication, work environment fluently.

At doctoral level: Students get familiar with publishing articles in local and well known international journals.

At Associate professor level: learners need to use advanced English in doing research and publish articles and books in well know publishers (ISI, WoS, Scopus, etc.)

\section{CONCLUSION}

There are various ways to enhance teaching methodology and research skills for students at all levels. OIn universities, we need to improve the curriculum, focus on improving the language proficiency of students. The current curriculum is still heavy in theory, has not focused on practice, the volume of subjects not related to the specialization is quite large. To meet the requirements of the quality of labor in the domestic and international market, the University should improve the curriculum to help students 
access advanced education and science. As a result, increasing soft skills, promoting group activities and improving students' foreign language skills. As a result, students will exploit the amount of valuable foreign references to serve their study and scientific research to improve the quality of their research. Students who are confident with their scientific research achievements promote their passion for research as well as attract people interested in and participate in scientific research from which the quantity and quality of the university's scientific research are enhanced. Secondly, promote activities to propagate and disseminate information about scientific research: Specialized faculties should coordinate with Youth Union, Student Union to organize seminars, exchange talks to introduce, equipping students with modern learning methods, building up right learning attitudes and research goals.

\section{ACKNOWLEDGEMENT}

This is a chance to express our warm thanks to editorial board, colleagues, family, brothers and friends to support this publication.

\section{REFERENCES}

Báo Lao động, Sinh Viên mới ra trường thất nghiệp do đâu. At: https://laodong.vn/archived/sinh-vienmoi-ra-truong-that-nghiep-do-dau-673015.ldo [date access 10/7/2019]

Báo Tuổi trẻ, Sinh viên thiếu kỹ năng, trường $Đ H$ vẫn chưa rõ phải dạy gì. At: https://tuoitre.vn/sinh-vienthieu-ky-nang-truong-dai-hoc-van-chua-ro-phai-day-gi-20181126215435446.htm > [date access 10/7/2019]

Conference: "Tăng cường năng lực nghiên cứu khoa học cho sinh viên trường đại học Tây Nguyên" tháng 12 năm 2014 tại trường đại học Tây Nguyên

George, M.L. (2020). Effective Teaching and Examination Strategies for Undergraduate Learning During COVID-19 School Restrictions, Journal of Educational Technology System, 3. https://doi.org/10.1177/0047239520934017

Omar, M.A.H, (2016), English Language Skills and Job Opportunities, Privileges, Personal Functions and EUses as Perceived by Seniors in Palestinian Universities, International Journal on Studies in English Language and Literature, 4(2): 5-11.

Mishra, L., Gupta, T., \& Shree, A. (2020). Online teaching-learning in higher education during lockdown period of COVID-19 pandemic, International Journal of Educational Research Open, 1. https://doi.org/10.1016/j.ijedro.2020.100012

Nguyễn Vân Anh.(2014). Các biện pháp quản lý nhằm tăng cường hoạt động nghiên cứu khoa học của Sinh viên trường Đại học Sư phạm - ĐHTN. Trường Đại học Sư phạm.

Nguyễn Thị Thu Trang, Sinh viên thất nghiệp sau khi ra trường - Nguyên nhân và cách khắc phục, Tạp chí Công thương. At: http://tapchicongthuong.vn/bai-viet/sinh-vien-that-nghiep-sau-khi-ra-truongnguyen-nhan-va-cach-khac-phuc-48972.htm [date access 10/7/2019]

Patricia, M., Thompson, G., \& Patrick, L. (2020). Theories of learning and teaching methods used in postgraduate education in the health sciences: a scoping review, Systematic Review, 18(1): 1-29. doi: 10.11124/JBISRIR-D-18-00022

Phòng Quản lý Khoa học. (2014). Danh muc đề tài NCKH \&CN các cấp. Trường ĐH Kinh tế \& QTKD.

Rapanta, C., Botturi, L., Goodyear, P., Guardia, L., \& Koole, M. (2020). Online University Teaching During and After the Covid-19 Crisis: Refocusing Teacher Presence and Learning Activity, Postdigital Science and Education, 2: 923-945

Saeed, M., \& Qunayeer, H.S.A. (2021). Can we engage postgraduates in active research methodology learning? Challenges, Strategies and Evaluation of learning, International Journal of Research \& Method in Education, 44(1). https://doi.org/10.1080/1743727X.2020.1728526

Shrestha, R.N., Awasthi, J.R., \& Pahari, B.R., (2018), Impact of English Language Proficiency on the Job Grabbing Process of Engineers in Nepal and the Other Countries: A Bird's Eye View, Journal of the Institute of Engineering, 14(1): 223-234.

Trường ĐH Kinh tế quốc dân. Quyết định số 1357/QĐKH của Hiệu trưởng về việc ban hành Quyết định Nghiên cứu khoa học của Sinh viên và Căn cứ theo công văn số 6716/BGDĐT-KHCNMT ngày $7 / 10 / 2011$.

Wedell, Martin. (2008). Developing a capacity to make "English for Everyone" worthwhile: Reconsidering outcomes and how to start achieving them. International Journal of Educational Development, 28(6): 628-639. 